\title{
Climate Variability and Small-Scale Fisheries in Kenya: Characterization of Current Socio- Economic Conditions of Artisanal Fishing Communities in Ungwana Bay and the Lower Tana Delta
}

\author{
Mumini Dzoga ${ }^{1,3 *}$, Mulala Danny Simatele ${ }^{1,2}$ and Cosmas Munga ${ }^{3}$ \\ ${ }^{1}$ Department of Geography and Environmental Studies, University of Wits, South Africa \\ ${ }^{2}$ Centre in Water Research and Development (CiWaRD), Department of Geography and Environmental Studies, University of Wits, South Africa \\ ${ }^{3}$ Department of Environment and Health Sciences, Marine and Fisheries Programme, Technical University of Mombasa, Kenya
}

Submission: February 18, 2019; Published: March 12, 2019

*Corresponding author: Mumini Dzoga, School of Geography, Archaeology and Environmental Studies; Department of Geography and Environmental Studies, University of Wits, P/B 3, 2050, Johannesburg, South Africa \& Department of Environment and Health Sciences, Marine and Fisheries Programme, Technical University of Mombasa, P.O. Box 90420-80100, Mombasa, Kenya

\begin{abstract}
Small-scale coastal fishing communities in the tropics have varied responses to climate variability constraints. These responses are often part of the different ways in which communities build adaptive capacity and resilience against internal and external stresses in their bid to reduce the impacts of prevailing and projected weather conditions. It is widely accepted that small-scale coastal fishing communities depend on fisheries resources for their livelihood. If these resources are increasingly becoming scarce as a result of climate variability pressure, a natural question to ask revolves around the ability of these fishing communities to employ alternative livelihood strategies. Drawing from a recent cross-sectional field study conducted in Ungwana Bay and the Lower Tana Delta, north coast of Kenya coupled with analysis of long -term terrestrial temperature and rainfall data, this paper describes the climate variability and the socio-economic status of the small-scale or artisanal fishing communities and how these communities are adapting to existing challenges. Trend in terrestrial temperature indicated a strong and positive correlation over time for the region $\left(R^{2}=0.7588\right)$. Small scale coastal fishing community's livelihood showed significant association with natural resource dependence $\left(P=0.001, \chi^{2}=494.153 \mathrm{a}\right)$. Furthermore, empirical evidence indicated that while fishing is an important source of livelihood in Ngomeni and Kipini, the Ozi fishing community has expanded its sources of livelihood to include crop production. Population pressure, low level of education, and unemployment have been identified as key socio-economic factors leading to the heavy dependence on natural resources for livelihood support $\left(\chi^{2}=24.273^{\mathrm{a}}, \mathrm{P}=0.004 ; \chi^{2}=46.319^{\mathrm{a}}, \mathrm{P}=0.001\right.$ and $\chi^{2}=17.863^{\mathrm{a}} ; \mathrm{P}=0.037$, respectively). It is recommended in this paper that the provision of both civic and formal education may play an important role in equipping fishing communities with knowledge for embracing and adopting alternative livelihood strategies and income generation opportunities. These strategies would also contribute to less pressure on the fisheries resources for sustainable livelihood.
\end{abstract}

Keywords: Weather conditions; Sustainable livelihood; Socio-economic factors; Climatic conditions; Natural hazards

\section{Introduction}

Natural and human environments are at high risk to climatic variability [1]. To a high degree, climate variability impacts have been manifested through degradation of natural environments which then affect the human environment through direct or indirect impacts, respectively [2,3]. The direct impacts encompass a range of natural hazards and extreme events such as increased soil salinity, drought and flooding while indirect impacts are manifested through deterioration in the social-economic elements $[1,4,5]$. Human livelihoods are intertwined with climatic conditions [6]. It has been argued that variations in temperature and rainfall affect human livelihoods especially for those communities whose livelihood systems are rainfall and ecosystem dependent [7]. Simatele et al. (2012) [8] have observed that variations in weather conditions tend to subject and compromise the ability of the poor people to secure sustainable livelihoods due to the fact that they lack the necessary asset portfolios to deploy and adapt to climate variability. 
Globally, artisanal or small-scale coastal fishing communities predominantly depend on fisheries resources for their livelihood and largely rely on low-productive traditional fishing methods thus coined as "poorest of the poor" [9]. Degradation of natural resources due to climate variability results to decline in catches. Mustapha et al. [10] noted that climatic extremes may compell abandonment of artisanal fisheries. Badjeck et al. [7] further argues for the need to understand the implications of climate variability on fishing communities in order to identify the entry point for policy implementation and decision making, foster livelihood diversification of grassroot communities, and strengthen institutions mandated with facilitating the adaptive capacity and resilience of vulnerable fishing communities.

The Ungwana Bay and Lower Tana Delta region in north coast Kenya, experiences condusive oceanographic conditions characterized by the South East Monsoon (SEM) and North East Monsoon (NEM) seasons prevailing from April to September, and October to March, respectively. These seasons favor a number of livelihood activities such as fishing [11]. The Ungwana Bay area, in particular, is widely known for its high biodiversity especially in fisheries and birds [12,13]. To a large extent, the area is known as home for artisanal fishing communities [14]. However, projections on climate variability in the entire region of north coast Kenya within which the study area is located, estimated an increase in temperature by $0.3^{\circ} \mathrm{C}$, as well as a decrease in rainfall by $25 \%$ by 2050 [15]. These climate projections have a potential to significantly and negatively affect the livelihood status of the many poor coastal communities as a result of the change in ecosystem services. In view of these observations, this paper characterizes and discusses the current climatic variability and socio-economic status of the artisanal fishing communities and how these communities are adapting to these challenges.

\section{Materials and Methods}

Data was collected using a cross-sectional socio-economic survey in three study sites namely: Ngomeni, Kipini, and Ozi typical of coastal fishing communities (Figure 1).

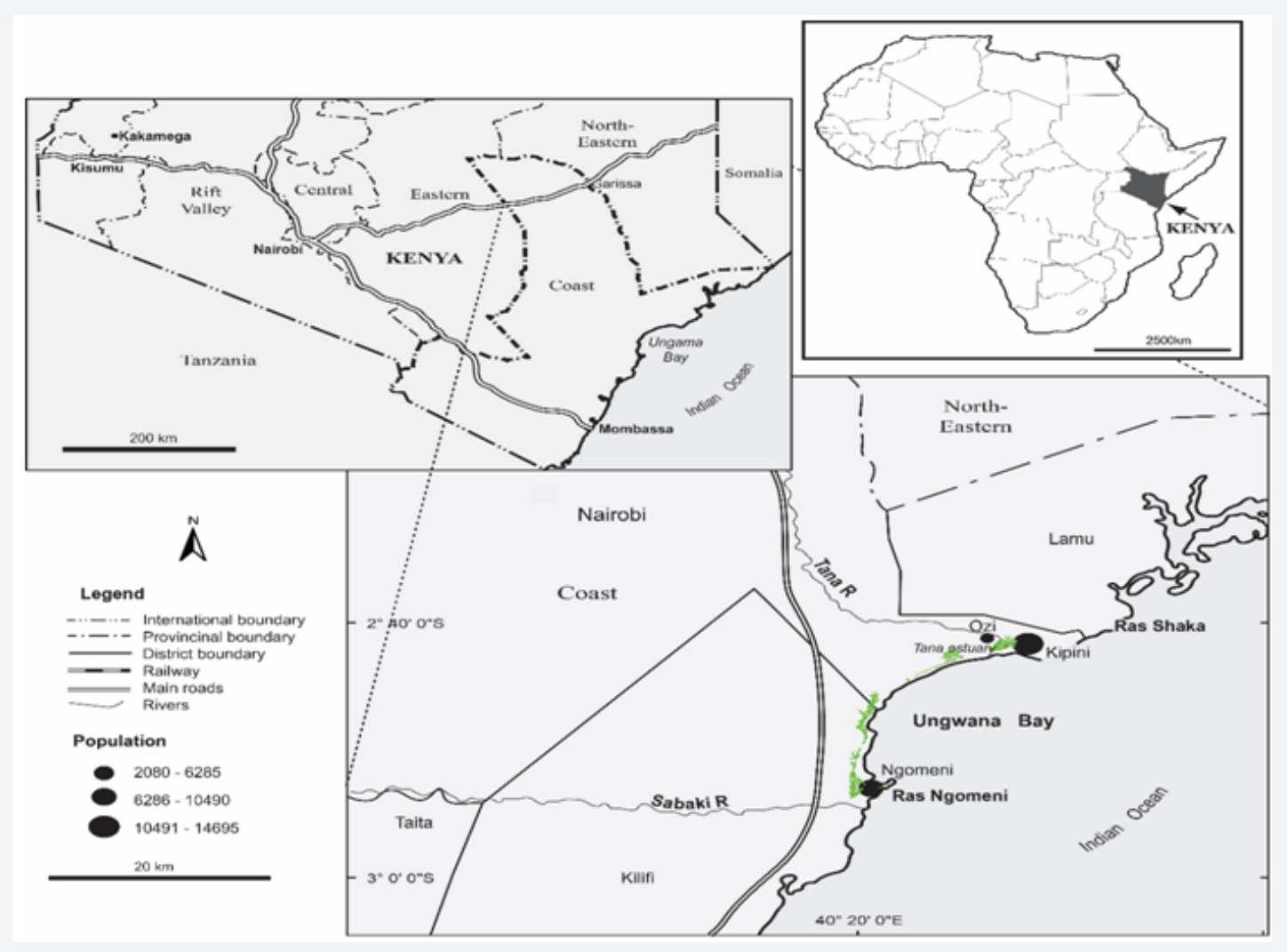

Figure 1: Map showing the study sites of Ngomeni, Kipini, and Ozi in Ungwana Bay and Lower Tana Delta, north coast, Kenya.

In order to draw a representative sample size of the study, the Cochran's [16] formula was employed:

$$
n_{o}=\frac{z^{2} p q}{e^{2}}
$$

Where:

$n_{0}=$ sample size, $z=$ is the selected critical value of desired level of confidence, $p=$ is the estimated proportion of an attribute that is present in the population,

$q=1-p$,

$e=$ is the desired level of precision 


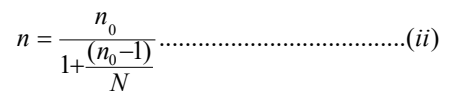

Where:

$\mathrm{n}=$ new sample size to be determined,

$\mathrm{n}_{0}=$ sample size derived from eq...(i),

$\mathrm{N}=$ actual population size of the subjects

The weight for each study site was determined by the following formula (iii) based on the total population of each area.

$$
w=n / N \text {........ }
$$

Where: $w=$ weight,

$n=$ Population for each stratum

$N=$ Total population for the three strata

The total population of Ngomeni, Kipini and Ozi was 10,241, 14,695 and 2,084 [17,18], respectively. A representative sample of 144, 206 and 29 individuals from Ngomeni, Kipini and Ozi were selected through a simple random process. Therefore, an overall total of 379 respondents were interviewed during the study period.

\section{Data collection}

Long term rainfall and terrestrial temperature data for the three study sites was obtained from the Kenya Meteorological Department, (i.e. Msabaha - Malindi station) spanning a period from 1999 to 2016. Semi-structured interviews using questionnaires were used for data collection. The questionnaires were administered by one on one interview of the respondents addressing their annual income from fishing activities, other sources of livelihood, natural resource dependence, and social factors. The respondents were selected through a simple random process which was conducted through the help of the respective area government administration officers and village elders. All the names of household heads of the fishing communities were assigned numbers and then a table of random numbers was generated and produced the order of sampling procedure and the sample size. The corresponding household names on the random numbers generated were then identified before engaged in the semi-structured interviews.

\section{Data analysis}

Mean and trends of rainfall and terrestrial temperature were computed using Microsoft Excel. Frequencies of socio-economic variables were coded and entered into SPSS software where respective variables were analyzed descriptively using actual values and relative percentages and then graphically represented. Chi-Square $\left(\chi^{2}\right)$ test was used to determine whether there was a significant association in natural resource dependence among the artisanal fishing community's livelihood, and whether there was a significant association in factors resulting in the dependence of the natural resources (fisheries, terrestrial forests, mangroves and land).

\section{Results}

\section{Rainfall and temperature variability}

Based on the 1999-2016 rainfall and terrestrial temperature data, the Ungwana Bay and Lower Tana Delta in north coast Kenya recorded a mean rainfall of $85.11 \pm 4.36 \mathrm{~mm}$ and terrestrial mean temperature of $30.55 \pm 0.08^{\circ} \mathrm{C}$. During the same period, rainfall showed a decreasing trend while terrestrial temperature indicated an increasing trend (Figure 2). The rainfall trend showed weak and positive correlation $\left(\mathrm{R}^{2}=0.178\right)$ with time while the trend in terrestrial temperature indicated a strong and positive correlation $\left(\mathrm{R}^{2}=0.7588\right)$ with time (Figure 2$)$.
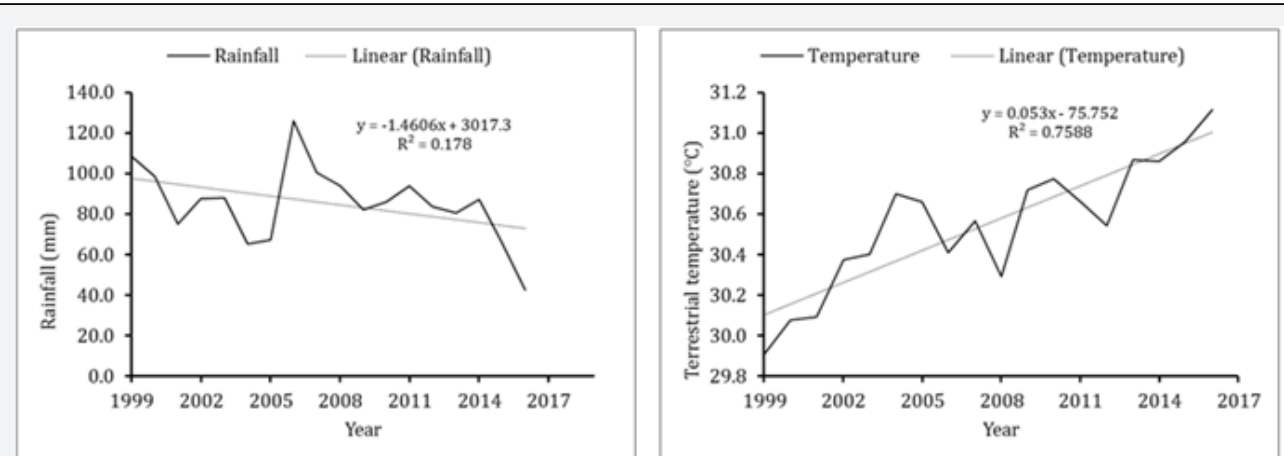

Figure 2: Mean annual trends of rainfall and terrestrial temperature between 1999 and 2016 in Ungwana Bay and Lower Tana Delta, in north coast Kenya (Data source: Kenya Meteorological Department, Malindi Station).

Socio-economic attributes of small-scale fishing communities

A total of 379 individuals were interviewed during the study period. The monthly average income on fisheries livelihood among the fishing communities in the three study sites varied.
Ngomeni showed relatively high monthly average income per person ( $\$ 52 \pm 4$ ) followed by Kipini at $\$ 33 \pm 2$ and Ozi at $\$ 24 \pm 3$ (Figure 3). The artisanal fishing communities of Ngomeni, Kipini and Ozi revealed high levels of unemployment of $88.2 \%, 88.3 \%$, and $93.1 \%$ respectively (Figure 4 ). Majority of the respondents 
attained elementary level of education where Ngomeni comprised of 54.9\%, Kipini (49.5\%), and Ozi with 53.6\% (Figure 5). Across all the study sites, perception on population growth status showed that the population has been increasing with time (Figure 6).

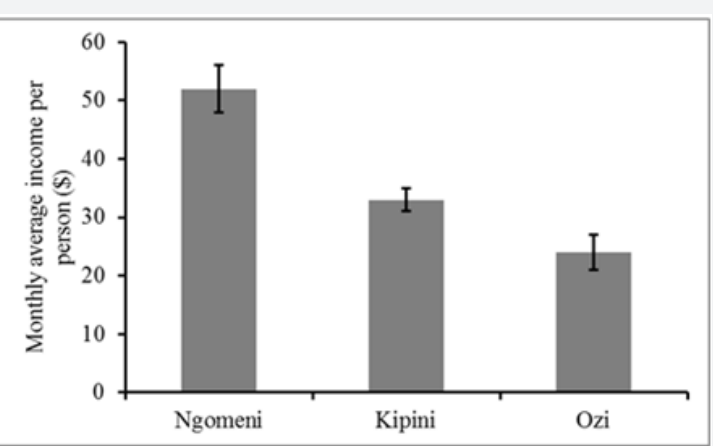

Figure 3: Annual average income per person of artisanal fishing communities in Ungwana Bay and Lower Tana Delta, Kenya (1 US $\$=101$ Ksh).

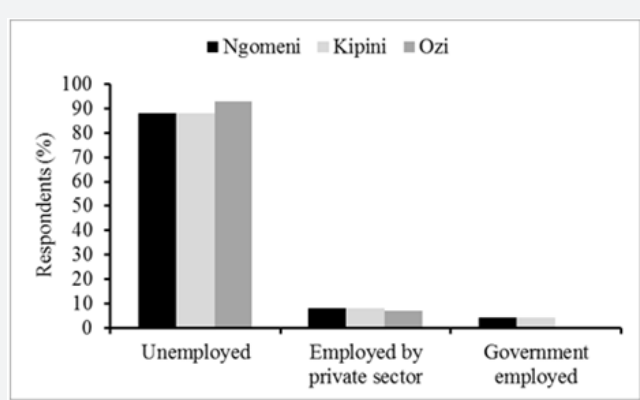

Figure 4: Employment status of respondents by study sites in Ungwana Bay and Lower Tana Delta, Kenya.

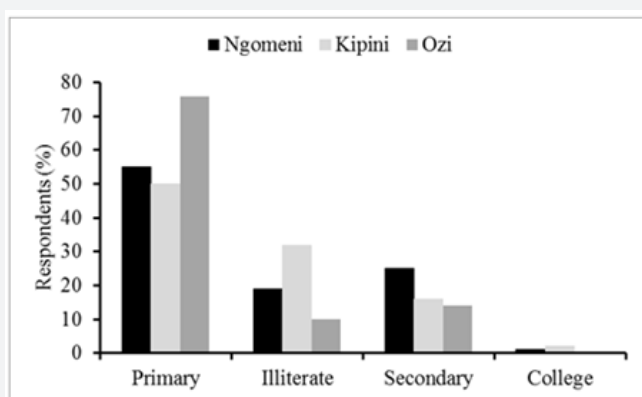

Figure 5: Education status of respondents by study sites in Ungwana Bay and Lower Tana Delta, Kenya.

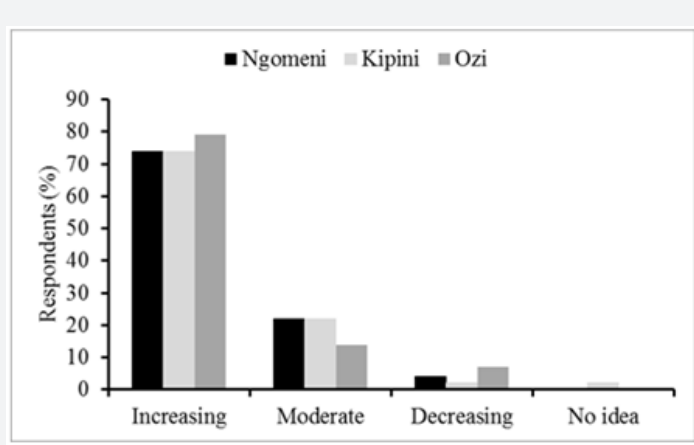

Figure 6: Perception on population growth based on outcome of the respondents by study sites in Ungwana Bay and Lower Tana Delta, Kenya. 
Dependence on natural resources by small-scale fishing communities

The dependence level on natural resources among the smallscale (artisanal) fishing communities varied across the study sites. In Ngomeni and Kipini sites, majority (66\% and 62\%, respectively) of the communities relied on fisheries resources while majority (66\%) of the fishing communities in Ozi relied on land resources (Table 1). The fishing communities indicated low dependence level on terrestrial forests across all the study sites (Table 1). Livelihood of the small-scale fishing communities showed significant association with the dependence on natural resources $\left(P=0.001, \chi^{2}=494.153 a\right)$.

Table 1: Dependence level (\%) on natural resources by small-scale fishing communities in Ungwana Bay and Lower Tana Delta, Kenya.

\begin{tabular}{|c|c|c|c|c|c|}
\hline Study Sites & Fisheries & Mangroves & Land & Terrestrial Forests & Other \\
\hline Ngomeni & 66 & 10 & 19 & 5 & 0 \\
\hline Kipini & 62 & 4 & 31 & 2 & 1 \\
\hline Ozi & 28 & 3 & 66 & 3 & 0 \\
\hline
\end{tabular}

Status of sources of livelihood and factors resulting to dependence on natural resources for livelihood support

Table 2:Composition (\%) of sources of livelihood for fishing communities in Ungwana Bay and Lower Tana Delta, Kenya.

\begin{tabular}{|c|c|c|c|c|c|c|c|c|c|c|}
\hline $\begin{array}{l}\text { Study } \\
\text { Area }\end{array}$ & Fishing & $\begin{array}{c}\text { Crop } \\
\text { Farming }\end{array}$ & $\begin{array}{c}\text { Livestock } \\
\text { Keeping }\end{array}$ & $\begin{array}{l}\text { Charcoal } \\
\text { Producers }\end{array}$ & $\begin{array}{c}\text { Formal } \\
\text { Employed }\end{array}$ & $\begin{array}{c}\text { Fish } \\
\text { Traders }\end{array}$ & $\begin{array}{c}\text { Food } \\
\text { Vendors }\end{array}$ & $\begin{array}{c}\text { Shell } \\
\text { Collectors }\end{array}$ & Hoteliers & Others \\
\hline Ngomeni & 74.3 & 6.9 & 2.1 & 4.9 & 3.5 & 0.7 & 2.1 & 0.7 & 1.4 & 3.5 \\
\hline Kipini & 57.8 & 18.9 & 8.7 & 2.4 & 2.9 & 7.3 & 1 & $\mathbf{0}$ & 1 & $\mathbf{0}$ \\
\hline Ozi & 44.8 & 48.3 & 3.4 & $\mathbf{0}$ & $\mathbf{0}$ & 3.4 & $\mathbf{0}$ & $\mathbf{0}$ & $\mathbf{0}$ & $\mathbf{0}$ \\
\hline
\end{tabular}

Fishing activity forms a core source of livelihood for artisanal fishing communities in Ngomeni with $74.3 \%$ and in Kipini with $57.8 \%$. However, the core source of livelihood for Ozi community is crop farming with $48.3 \%$ and to some extent fishing with $44.8 \%$ (Table 2). Results of Chi-Square test indicated significant association between natural resource dependence with population growth $\left(\chi^{2}=24.273^{\mathrm{a}} ; P=0.004\right)$, with education $\left(\chi^{2}=46.319^{\mathrm{a}} ; P=\right.$ $0.001)$, and with employment $\left(\chi^{2}=17.863^{\mathrm{a}} ; P=0.037\right)$.

\section{Discussion}

The Ungwana Bay and Lower Tana Delta region in north coast Kenya is characterized by increasing variability of rainfall and terrestrial temperature. Though weak correlation was observed on rainfall over time, the decreasing rainfall trend in the study area has been reported in several studies $[15,19]$. Langat et al. (2017) [19] in their study of rainfall variability in the Tana River Basin noted that while rainfall is characterized by increasing trends in the upstream (high lands), the downstream (coastal lands) is characterized by decreasing trends. Thus, the Tana River flow is highly influenced by the amount of rainfall upstream. Furthermore, Langat et al. (2017) [19] also noted that the Tana Delta receives a mean annual rainfall of $79.57 \mathrm{~mm}$ against a mean annual of $85.11 \pm 4.36 \mathrm{~mm}$ recorded in this study. In addition, Deenapanray and Tan [15] projected a decrease of the rainfall in the region by $25 \%$ in 2050 . Notably, terrestrial temperature according to this study has shown increasing trend as well as strong and positive correlation over time. Likewise, projections have estimated an increase in temperature in the region by $0.3^{\circ} \mathrm{C}$ in 2050 [15]. Therefore, rainfall and temperature variability in the study area is apparent with already observed implications to the small-scale fishing communities as found out in this study.
The small-scale fishing communities in Ungwana Bay and Lower Tana Delta, north coast Kenya are similar to the rest of tropical coastal artisanal communities globally characterized by low mean annual income, high level of unemployment, and low level of education. Similarly, Perret [20] observed that majority (54\%) of the small-scale fishing communities in Singkaraka Lake, Indonesia had attained elementary education while Paudel et al. [21] showed that $69 \%$ of the artisanal fishing communities in Nepal were illiterate. Attainment of basic education limits accessibility to decent employment opportunities due to low level of skills. Higher education on the other hand is important for skilled labour and productive workforce thus enhance high standard of living [22]. Comparable to the relatively low monthly average income per person of the small-scale fishing communities in Ngomeni ( $52 \pm 4$ ), Kipini ( $33 \pm 2$ ), and Ozi (\$24 \pm 3 ), most of the artisanal fishing communities in Nepal were reported to have a slightly high monthly average income of $\$ 60.2 \pm 2.6$ from fisheries [21]. The overall population trend of the artisanal fishing communities in Ungwana Bay and Lower Tana Delta has been increasing. Secours Islamique France (SIF) [23] confirmed the Tana Delta region has experienced population growth that has turned more land into settlement schemes and farming.

While the small-scale fishing communities are still dependent on fisheries resources despite the prevailing climatic challenges globally [20,21], these fishing communities have also been engaging in other sources of livelihood especially for Ozi community where crop farming seems to be slighlty more important than fishing. This may be attributed to the general observation of core livelihood activities in the Tana Delta region which is characterized by farming and pastoralism [23]. Other livelihood 
such as fishing, hunting and honey gathering are considered less important in the region [23]. On the other hand, crop farming is less important for Ngomeni and Kipini communities. Ngomeni and Kipini are adjacent to the Indian Ocean thus rely mostly on fisheries resources for livelihood. However, the current fisheries dependency level for Ngomeni (74\%) and Kipini (58\%) is lower compared to the dependency level reported by Kitheka [24] in Ngomeni and Kipini $(90 \%, 70 \%)$ respectively. This may be due to climate variability challenges experienced and possible expansion of livelihood sources.

Demographic factors such as population growth have been observed to accelerate environmental degradation due to high dependency on natural resources [25]. In this study, population growth, unemployment and low level of education are the factors that cause high dependency on natural resources among the artisanal fishing communities. Lack of employment, population growth and low level of education compel communities to rely on natural resources thus resulting to resources deterioration [26]. Paudel et al. [20] confirmed this in their study where the artisanal fishing communities in Nepal recommended better education and alternative occupations to conserve their ecological resources of Ganges River dolphin. Thus, poor education and lack of employment may force fishing communities to exert pressure on natural resources.

\section{Conclusion}

The Ungwana Bay and Lower Tana Delta ecosystem is exposed to increasing terrestrial temperature and decreasing rainfall over time. The ecosystem is an important source of livelihoods to the local communities with an increasing population growth. Majority of the artisanal fishing communities are poorly educated and unemployed with resultant high pressure dependency on the available natural resources. The climatic variability coupled with anthropogenic pressure may impact the fisheries resources and in turn affect the fishing communities. The artisanal fishing communities need to expand their sources of livelihood to include other feasible activities such as crop farming especially for Ngomeni and Kipini communities. Therefore, there is need for community sensitization on climate variability impacts, provision of education and improved crop production to balance between sustainable resource use and environmental management.

\section{Acknowledgement}

We are grateful to the National Research Foundation (NRF), South Africa for awarding a PhD scholarship to MD during the 2016 NRF TWAS Doctoral scholarship. It is through this opportunity that enabled this study. We are also grateful to the National Research Fund (NRF) of Kenya for co-funding this study through awarding of a research grant. We would like to thank Jonathan Ngayai of Kenya Meteorological Department, (KMD) Msabaha Station in Malindi for provision of the long-term data sets for the climatic variables.

\section{References}

1. McMichael AJ, Campbell-Lendrum DH, Corvalán CF, Ebi KL, Githeko AK, et al. (2003) Climate change and human health : risks and responses. Geneva: World Health Organization.

2. Scott MJ, Rosenberg NJ, Edmonds JA, Cushman RM, Darwin RF, et al. (1990) Consequences of Climatic Change for the Human Environment. Climate Research 1: 63-79.

3. Cahoon DR, Hansel P (2002) Hurricane Mitch: a regional perspective on mangrove damage, recovery and sustainability. USA: USGS Open File Report 03-183, p. 31.

4. Cruz RV, Harasawa H, Lal M, Wu S, Anokhin Y, et al. (2007) Climate Change 2007: Impacts, Adaptation and Vulnerability. In: Parry MI, Canziani OF, Palutikof JP, Linden PJ, Hanson CE (Eds.), Contribution of Working Group II to the Fourth Assessment Report of the International Panel on Climate Change. Camridge University Press, Cambridge, UK, pp. 469-506.

5. Anderson P, Brownstein J, Confalonieri U, Causey D, Chan N, et al. (2006) Climate Change Futures: Health, Ecological and Economic Dimensions. Harvad Medical School, The Center for Health and the Global Environment.

6. Trenberth KE, Miller K, Mearns L, Rhodes S (2000) Effects of Changing Climate on Weather and Human Activities. California: University Corporation for Atmospheric Research.

7. Badjeck MC, Allison EH, Halls AS, Dulvy NK (2010) Impacts of climate variability and change on fishery-basedlivelihoods. Marine Policy 34(3): 375-383.

8. Simatele D, Binns T, Simatele M (2012) Sustaining Livelihoods under a Changing Climate: The case of urban agriculture in Lusaka, Zambia. Journal of Environmental Planning and Management pp. 1-17.

9. Allison EH, Ellis F (2001) The Livelihoods Approach and Management of Small-Scale Fisheries. Marine Policy 25(5): 377-388.

10. Mustapha J (2013) Potential Impacts of Climate Change on Artisanal Fisheries of Nigeria. Earth Science \& Climatic Change, p. 6.

11. Munga C, Ndegwa S, Fulanda B, Manyala J, Kimani E, et al. (2012) Bottom shrimp trawling impacts on species distribution and fishery dynamics; Ungwana Bay fishery Kenya before and after the 2006 trawl ban. Fisheries Science 78(2): 209-219.

12. Abila R (2010) Economic Evaluation of the Prawn Fishery of the Malindi-Ungwana Bay along Kenya's Coast. Kisumu, Kenya: Kenya Marine and Fisheries Research Institute.

13. Munga CN, Kimani E, Ruwa RK, Vanreusel A (2016) Species composition of fisheries resources of the Tana and Sabaki Estuaries in the Malindi-Ungwana Bay, Kenya. In: Diop S, Scheren P, Machiwa J (Eds.), Estuaries: A lifeline of ecosystem services in the Western Indian Ocean, pp. $27-38$.

14. Government of Kenya (2015) The Malindi-Ungwana Bay Fishery CoManagement Plan (2016-2021). Ministry of Agriculture, Livestock and Fisheries, p. 33.

15. Deenapanray PN, Tan Z (2011) Strengthening Institutional Capacity for Integrated Climate Change Adaptation \& Comprehensive National Development Planning in Kenya. Millenium Institute, Wasington, DC 20006, USA.

16. Cochran WG (1977) Sampling Techniques ( $3^{\text {rd }}$ edn). John Wiley and Sons, New York, USA.

17. Government of Kenya (2009) 2009 Kenya Population and Housing Census. Nairobi: Government Printer. 
18. Government of Kenya (2010) National Climate Change Response Strategy. Nairobi: Government of Kenya.

19. Langat PK, Kumar L, Koech R (2017) Temporal Variability and Trends of Rainfall and Streamflow in Tana River Basin, Kenya. Sustainability, p. 18.

20. Perret SR (2010) Livelihood Features of Small Scale Fishing Communities: A Case from Singkarak Lake, West Sumatra, Indonesia. International Journal of Environmental and Rural Development, pp. 94-101.

21. Paudel S, Levesque JC, Saavedra C, Pita C, Pal P (2016) Characterization of the artisanal fishing communities in Nepal and potential implications for the conservation and management of Ganges River Dolphin (Platanista gangetica gangetica). Peer J 4: e1563.

22. International Labour Organization (2011) A Skilled Workforce for Strong, Sustainable and Balanced Growth: A G20 Training Strategy. Geneva: International Labour Organization.
23. Secours Islamique France (2013) Tana River, Tana Delta, Ijara, Lamu, Assessment report. Ijara, Tana River County: Secours Islamique France.

24. Kitheka JU (2002) Freshwater and sediment discharge in Ungwana Bay: The role of the Tana and Sabaki rivers. In Current Status of Trawl Fishery of Malindi-Ungwana Bay. Mombasa: Kenya Marine and Fisheries and Research Institute, p. 97.

25. Harte J (2007) Human population as a dynamic factor in environmental degradation. Population Environment 28(4-5): 223-236.

26. Hammad AA, Tumeizi A (2010) Land Degradation: Socioeconomic and Environmental Causes and Consequences in the Eastern Mediterranean. Land Degradation and Development 23(3): 216- 226.

\section{Your next submission with Juniper Publishers will reach you the below assets}

- Quality Editorial service

- Swift Peer Review

- Reprints availability

- E-prints Service

- Manuscript Podcast for convenient understanding

- Global attainment for your research

- Manuscript accessibility in different formats ( Pdf, E-pub, Full Text, Audio)

- Unceasing customer service

Track the below URL for one-step submission https://juniperpublishers.com/online-submission.php 